\title{
DNA-Binding Activity and Cytotoxicity of the Extended Diphenylfuran Bisamidines in Breast Cancer MCF-7 Cells
}

\author{
Krzysztof BielawsKi, ${ }^{*},{ }^{a}$ Sławomir WolczyŃski, ${ }^{b}$ and Anna BielawsKa ${ }^{a}$ \\ Department of Medicinal Chemistry and Drug Technology, Medical Academy of Białystok, ${ }^{a}$ Mickiewicza 2, 15-230 Biat- \\ ystok, Poland and Department of Gynecological Endocrinology, Medical Academy of Biatystok, ${ }^{b}$ Sktodowskiej 24A, \\ 15-276 Białystok, Poland. Received December 18, 2000; accepted February 27, 2001
}

The DNA binding properties of three novel extended diphenylfuran bisamidines (1-3) possessing different dicationic terminal side chains were studied. The ultrafiltration assay showed that bisamidines $1-3$ have significant affinity for DNA. The DNA-binding data for bisamidines $1-3$ using homopolymers poly (dA-dT) $\cdot$ poly(dAdT) and poly $(\mathrm{dG}-\mathrm{dC}) \cdot \operatorname{poly}(\mathrm{dG}-\mathrm{dC})$, indicated that these compounds show moderate specificity for AT base pairs. We studied the cytotoxicity effects of bisamidines 1-3, Hoechst 33258 and DAPI (4',6-diamidino-2-phenylindole) in cultured breast cancer MCF-7 cells. The bisamidines 1-3 showed comparable antitumour activity to Hoechst 33258, but were substantially more cytotoxic compared to DAPI. These data show that in broad terms the cytotoxic potency of bisamidines $1-3$ in cultured breast cancer MCF-7 cells decreases with the size of the alkyl group substituent (cyclopropyl>isopropyl>cyclopentyl), in accord with their increases in DNA affinity, as shown by the binding constant values.

Key words bisamidine; DNA-binding; utrafiltration assay; breast cancer MCF-7 cells

The aromatic bisamidines exhibit a wide spectrum of antimicrobial, antiviral, and antitumour properties. ${ }^{1-3)}$ However, the precise genomic targets and modes of action of these ligands are not known. Most studies have focused on the abilities of bisamidines to inhibit the binding of regulatory proteins to oligonucleotide length recognition sequences that are rich in $\mathrm{A}$ and $\mathrm{T}$ base pairs. ${ }^{4-6)}$ The lack of a quantitative correlation between DNA binding and antimicrobial and antitumour activity for these molecules against all of the organisms studied can be attributed to the idea that DNA binding is only the first step in a multistep process. This paper reports the DNA binding affinity and base pair specificity for three extended diphenylfuran bisamidines 1-3 possessing different dicationic terminal side chains (Fig. 1). The DNA-binding ability of these bisamidines was evaluated by an utrafiltration method using calf thymus DNA, poly(dA$\mathrm{dT}) \cdot \operatorname{poly}(\mathrm{dA}-\mathrm{dT})$, poly $(\mathrm{dG}-\mathrm{dC}) \cdot \operatorname{poly}(\mathrm{dG}-\mathrm{dC})$ homopolymers, and used these data to compare the base-sequence specificity of bisamidines $\mathbf{1}-\mathbf{3}$ with DAPI and Hoechst $33258 .{ }^{7,8)}$ We report here on the cytotoxicity effects of bisamidines $\mathbf{1}-\mathbf{3}$ in cultured breast cancer MCF-7 cells.

\section{MATERIALS AND METHODS}

Reagents and Materials Synthesis of the compounds 1-3 have been described. .) DAPI (4',6-diamidino-2phenylindole), Hoechst 33258 (2-[2-(4-hydroxyphenyl)-6benzimidazolyl]-6-(1-methyl-4-piperazinyl)benzimidazole), ethidium bromide and 3-(4,5-dimethylthiazole-2-yl)-2,5diphenyltetrazolium bromide (MTT) were purchased from Sigma Chemical Co., (U.S.A.). Calf thymus DNA, homopolymers poly $(\mathrm{dA}-\mathrm{dT}) \cdot \operatorname{poly}(\mathrm{dA}-\mathrm{dT})$ and poly $(\mathrm{dG}-\mathrm{dC}) \cdot \operatorname{poly}(\mathrm{dG}-$ dC) were purchased from Sigma. Dulbecco's minimal essential medium (DMEM) and foetal bovine serum (FBS) used in cell culture were products of Gibco (U.S.A.). Glutamine, penicillin and streptomycin were obtained from Quality Biologicals Inc. (U.S.A.). $\left[{ }^{3} \mathrm{H}\right]$ Thymidine $(6.7 \mathrm{Ci} / \mathrm{mmol})$ was the product of NEN (U.S.A.).

Ultrafiltration Method A test compound $(100 \mu \mathrm{M})$ was mixed with calf thymus DNA (0.5 mM as base pairs) in 1.0 TB buffer (10 mm Tris $\cdot \mathrm{HC} 1$ (pH 8)-1 mm EDTA containing $0.15 \mathrm{M} \mathrm{NaCl})$. The mixture was allowed to stand at room tem-
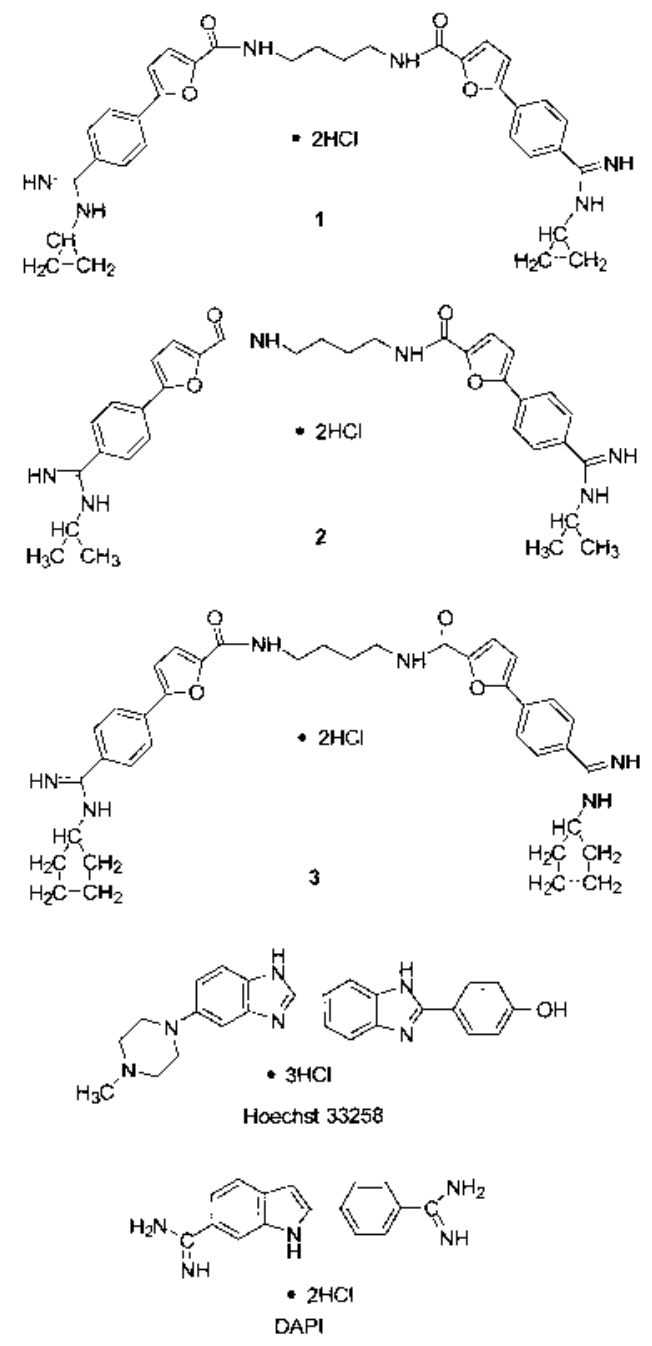

Fig. 1. Structure of Bisamidines 1-3, Hoechst 33258 and DAPI 
perature overnight. The mixture was ultrafiltered using a ultrafree-MC centrifugal filter unit (PLCC NMWL 5000, Milipore) at $20^{\circ} \mathrm{C}$, then the content of the test compound in the filtrate was determined by UV-absorption measurement $\left(\mathrm{Abs}_{\mathrm{DNA}^{+}}\right)$and this value was taken as the concentration of free compound ([comp $\left.]_{\mathrm{DNA}+}\right)$. The same procedure was carried out with a solution of the test compound in the absence of DNA as the control (Abs. ${ }_{\mathrm{DNA}-}$ and $[\text { comp }]_{\mathrm{DNA}-}$, respectively). Measurements were made with a Unicam/Helios $\gamma$ $\mathrm{UV}$-vis spectrophotometer at the maximum wavelengths above $300 \mathrm{~nm}$ for bisamidines $\mathbf{1}-\mathbf{3}$, DAPI and Hoechst 33258 (Table 1). Results are the means of three independent experiments. The DNA-binding ability of the test compound was defined by the following equation:

$$
\text { DNA binding ability } \begin{aligned}
(\%) & =\left(1-[\mathrm{comp}]_{\mathrm{DNA}+} /[\mathrm{comp}]_{\mathrm{DNA}-}\right) \times 100 \\
& =\left(1-\mathrm{Abs}_{\mathrm{DNA}+} / \mathrm{Abs}_{\mathrm{DNA}-}\right) \times 100
\end{aligned}
$$

MCF-7 Cultures Breast cancer MCF-7 cells were maintained in DMEM supplemented with $10 \% \mathrm{FBS}, 50 \mu \mathrm{g} / \mathrm{ml}$ penicillin, $50 \mu \mathrm{g} / \mathrm{ml}$ streptomycin at $37^{\circ} \mathrm{C}$ in a $5 \% \mathrm{CO}_{2}$ incubator. Cells were cultured in Costar flasks and subconfluent cells were detached with $0.05 \%$ trypsin, $0.02 \%$ EDTA in calcium-free phosphate-buffered saline, counted in hemocytometers and inoculated at $5 \times 10^{5}$ cells per well of six-well plates (Nunc, Wiesbaden, Germany) in $2 \mathrm{ml}$ of growth medium. Cells reached about $80 \%$ of confluence at day 3 after inoculation and in most cases such cells were used for the assays.

Cytotoxic Assay To examine the effect of studied drugs on fibroblast proliferation, the cells were seeded in 24 well tissue culture dishes at $1 \times 10^{5}$ cells/well with $1 \mathrm{ml}$ of growth medium. After $48 \mathrm{~h}\left(1.8 \pm 0.1 \times 10^{5}\right.$ cells/well $)$ plates were incubated with varying concentrations of bisamidines $\mathbf{1}-\mathbf{3}$, DAPI and Hoechst 33258 and $0.5 \mu \mathrm{Ci}$ of $\left[{ }^{3} \mathrm{H}\right]$ thymidine for $24 \mathrm{~h}$ at $37^{\circ} \mathrm{C}$. Cells were rinsed 3 times with PBS, solubilized with $1 \mathrm{ml}$ of $0.1 \mathrm{~mol} / 1$ sodium hydroxide containing $1 \%$ SDS, scintillation fluid $(9 \mathrm{ml})$ was added and radioactivity incorporation into DNA was measured in scintillation counter.

Cell Viability Assay The assay was performed according to the method of Carmichael using 3-(4,5-di-methylthiazole-2-yl)-2,5-diphenyltetrazolium bromide (MTT). ${ }^{10)}$ Confluent cells, cultured for $48 \mathrm{~h}$ with various concentrations of studied bisamidines in 6-well plates were washed three times with PBS and then incubated for $4 \mathrm{~h}$ in $1 \mathrm{ml}$ of MTT solution $(0.5 \mathrm{mg} / \mathrm{ml}$ of PBS $)$ at $37^{\circ} \mathrm{C}$ in $5 \% \mathrm{CO}_{2}$ in an incubator. The medium was removed and $1 \mathrm{ml}$ of $0.1 \mathrm{~mol} / 1 \mathrm{HCl}$ in absolute isopropanol was added to attached cells. Absorbance of con- verted dye in living cells was measured at a wavelength of $570 \mathrm{~nm}$. Cell viability of breast cancer MCF-7 cells cultured in the presence of ligands was calculated as a per cent of control cells.

Statistical Analysis In all experiments, the mean values for six independent experiments \pm standard deviations (S.D.) were calculated, unless otherwise indicated. The results were submitted to statistical analysis using Students $t$-test, accepting $p<0.05$, as significant.

\section{RESULTS AND DISCUSSION}

The DNA-binding ability of bisamidines $\mathbf{1}-\mathbf{3}$ was evaluated by the ultrafiltration method. ${ }^{7,8)}$ The binding constants $K_{\mathrm{a}}$ and number of sites per nucleotide $n$ were estimated from Scatchard plots using the classical Scatchard equation for independent binding sites without cooperativity. ${ }^{11)}$ The ultrafiltration assay using calf thymus DNA showed that the DNAbinding ability of bisamidines $\mathbf{1}-\mathbf{3}$ were similar to that of Hoechst 33258 (Table 1). The order of DNA-binding under the utrafiltration assay conditions of the test bisamidines is DAPI $>$ Hoechst $33258>\mathbf{1}>\mathbf{2}>\mathbf{3}$. As can be seen from the Table 1 , the binding constant $\left(K_{\mathrm{a}}\right)$ for bisamidines $\mathbf{1}-\mathbf{3}$ varies from $6.6 \times 10^{3} \mathrm{M}^{-1}$ for compound 1 to $3.9 \times 10^{3} \mathrm{M}^{-1}$ for compound 3. The binding of bisamidines $\mathbf{1}-\mathbf{3}$ is weaker than that of DAPI and Hoechst 33258. The enhanced flexibility of bisamidines $\mathbf{1}-\mathbf{3}$ would lower the probability of compounds $\mathbf{1}-\mathbf{3}$ occupying the correct region of conformational space and increase the entropy loss upon binding, both of which will lead to decreasing binding affinities. It may explain the lower DNA-binding properties of bisamidines $\mathbf{1}-\mathbf{3}$ compared to Hoechst 53228 and DAPI (Table 1).

Since calf thymus DNA is heterogeneous in base sequence and about $42 \%$ GC, the DNA-binding ability with calf thymus DNA characterizes the strength of the interaction with heterogeneous base sequences. The homopolymer DNAbinding data reported in Table 2 characterizes the affinity of the bisamidines $\mathbf{1}-\mathbf{3}$ for a more limited set of DNA-binding sites and can give an indication of base-sequence specificity for DNA-binding molecules. The bisamidines $\mathbf{1}-\mathbf{3}$ bind to AT sequences more weakly than the extensively studied minor-groove binders, such as distamycin A and netropsin. ${ }^{8)}$ However, bisamidines $\mathbf{1}-\mathbf{3}$ show sequence-selectivities: compounds 1, 2 and $\mathbf{3}$ bind to AT sequences 2 times more strongly than to CG sequences. As shown in Table 2, these values are similar to the values of Hoechst 33258. DAPI can also act as an intercalator in GC sequences ${ }^{12)}$ and showed

\begin{tabular}{|c|c|c|c|c|c|c|c|}
\hline \multirow[b]{2}{*}{ Compound } & \multirow[b]{2}{*}{$\begin{array}{l}\lambda_{\max } \\
(\mathrm{nm})\end{array}$} & \multirow[b]{2}{*}{$\begin{array}{c}\text { Abs. } \\
\operatorname{DNA}(-)^{a)}\end{array}$} & \multirow[b]{2}{*}{$\begin{array}{c}\text { Abs. } \\
\left.\operatorname{DNA}(+)^{a}\right)\end{array}$} & \multirow[b]{2}{*}{$\begin{array}{c}\text { DNA-binding } \\
\text { ability }^{b)} \\
(\%)\end{array}$} & \multicolumn{3}{|c|}{ Scatchard analyses } \\
\hline & & & & & $\begin{array}{c}\text { Binding constant } \\
\left(K_{\mathrm{a}}\right) \\
\left(10^{3} \mathrm{M}^{-1}\right)\end{array}$ & $\begin{array}{l}\text { Binding } \\
\text { sites }(n) \\
(\text { per bp) }\end{array}$ & $\begin{array}{c}\text { Correlation } \\
\text { coefficient } \\
(R)\end{array}$ \\
\hline Hoechst 33258 & 341 & 0.469 & 0.143 & 69.5 & 7.2 & 0.4 & 0.76 \\
\hline DAPI & 340 & 0.384 & 0.090 & 76.6 & 8.9 & 0.5 & 0.80 \\
\hline 1 & 323 & 0.775 & 0.266 & 65.7 & 6.6 & 0.4 & 0.81 \\
\hline 2 & 320 & 0.576 & 0.245 & 57.5 & 4.3 & 0.6 & 0.91 \\
\hline 3 & 326 & 0.668 & 0.310 & 53.6 & 3.9 & 0.5 & 0.88 \\
\hline
\end{tabular}

Table 1. DNA-Binding Abilities of Bisamidines 1-3, DAPI and Hoechst 33258 Determined by Utrafiltration Assay Using Calf Thymus DNA

a) The UV-absorption was measured at $\lambda_{\max }$ after 5 dilution with 1.0 buffer. $\left.\quad b\right)$ DNA binding ability $(\%)=\left(1-\mathrm{Abs}_{\mathrm{DNA}_{+}} / \mathrm{Abs}_{\mathrm{DNA}_{-}}\right) \times 100$. 
Table 2. Base Pair Specificity of Bisamidines 1-3, DAPI and Hoechst 33258 Determined by Utrafiltration Assay

\begin{tabular}{cccc}
\hline \hline & & \multicolumn{2}{c}{ DNA-binding ability (\%) } \\
\cline { 3 - 4 } Compound & $\begin{array}{c}\lambda_{\max } \\
(\mathrm{nm})\end{array}$ & AT & GC \\
& & 81.4 & 41.5 \\
Hoechst 33258 & 341 & 87.5 & 62.4 \\
DAPI & 340 & 78.4 & 37.4 \\
$\mathbf{1}$ & 323 & 70.9 & 36.5 \\
$\mathbf{2}$ & 320 & 71.6 & 34.6 \\
$\mathbf{3}$ & 326 & & \\
\hline
\end{tabular}

AT refers to poly $(\mathrm{dA}-\mathrm{dT}) \cdot \operatorname{poly}(\mathrm{dA}-\mathrm{dT})$ and $\mathrm{GC}$ to poly $(\mathrm{dG}-\mathrm{dC}) \cdot \operatorname{poly}(\mathrm{dG}-\mathrm{dC})$. The UV-absorption was measured at $\lambda_{\text {max }}$ after 5 dilution with 1.0 buffer.

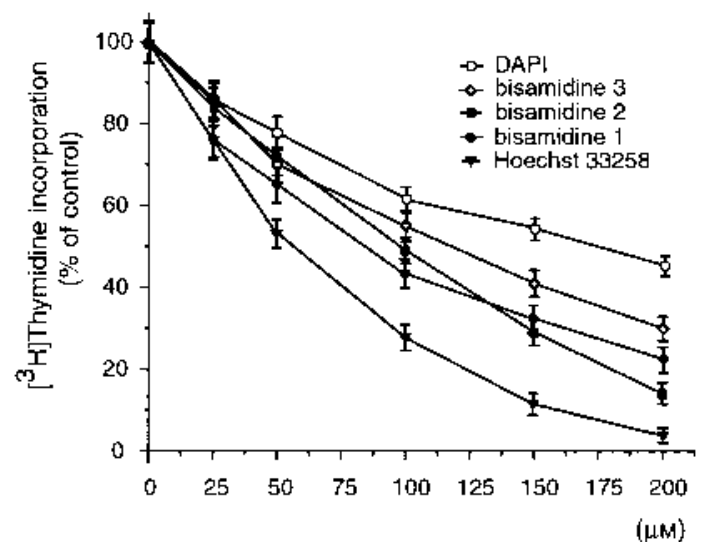

Fig. 2. Cytotoxic Effects of Bisamidines 1-3, Hoechst 33258 and DAPI on Cultured Breast Cancer MCF-7 Cells as Measured by Inhibition of $\left[{ }^{3} \mathrm{H}\right]$ Thymidine Incorporation into DNA

moderate AT specificity. The moderate AT base pair specificity shown by these bisamidines (Table 2) could be the result of the highly electropositive bisamidines binding preferentially to the most electronegative region of the DNA, the AT base pairs in the minor groove. ${ }^{13)}$

Bisamidines such as furimidazoline and furamidine have demonstrated diverse pharmacological activities.,3) They show significant antiproliferative activities against various tumor cell lines, including cells resistant to cisplatinum. ${ }^{3)} \mathrm{We}$ studied the effect of bisamidines $\mathbf{1}-\mathbf{3}$, Hoechst 33258 and DAPI on DNA synthesis in cultured breast cancer MCF-7 cells (Fig. 2). The $\mathrm{IC}_{50}$ of bisamidines $\mathbf{1}, \mathbf{2}$ and $\mathbf{3}$ for DNA synthesis was found to be $85 \mu \mathrm{m}, 97 \mu \mathrm{m}$ and $117 \mu \mathrm{m}$ respectively, suggesting similar cytotoxic potency for bisamidines 1 and 2 compared to Hoechst $53228\left(\mathrm{IC}_{50}=55 \mu \mathrm{M}\right)$ and a higher cytotoxic potency compared to DAPI $\left(\mathrm{IC}_{50}=176 \mu \mathrm{M}\right)$. Cell viability was measured by the method of Carmichael using tetrazolium salt. ${ }^{10)}$ There was only a slight difference in the cytotoxicity of the bisamidines $\mathbf{1}-\mathbf{3}$. As can be seen bisamidines $\mathbf{1}-\mathbf{3}$ at the concentration of $75 \mu \mathrm{M}$ produced about a $30 \%$ reduction in cell viability in breast cancer MCF7 cells. A similar cytotoxicity activity for Hoechst 33258 was observed. DAPI had significantly lower toxicity on the cells
Table 3. Viability of MCF-7 Cells Treated for $48 \mathrm{~h}$ with Different Concentrations of Bisamidines $\mathbf{1}-\mathbf{3}$, Hoechst 33258 and DAPI

\begin{tabular}{cccccc}
\hline \hline \multirow{2}{*}{$\begin{array}{c}\text { Concentration } \\
(\mu \mathrm{M})\end{array}$} & $\mathbf{5}$ Viability of cells (\% of control) \\
\cline { 2 - 6 } & $\mathbf{1}$ & $\mathbf{2}$ & $\mathbf{3}$ & Hoechst 33258 & DAPI \\
\hline 0 & 100 & 100 & 100 & 100 & 100 \\
10 & $92 \pm 2$ & $90 \pm 2$ & $93 \pm 2$ & $83 \pm 2$ & $93 \pm 2$ \\
25 & $89 \pm 3$ & $87 \pm 2$ & $89 \pm 2$ & $75 \pm 2$ & $89 \pm 2$ \\
50 & $82 \pm 2$ & $80 \pm 2$ & $83 \pm 2$ & $67 \pm 2$ & $82 \pm 2$ \\
75 & $69 \pm 1$ & $68 \pm 2$ & $75 \pm 2$ & $56 \pm 2$ & $79 \pm 2$ \\
100 & $58 \pm 1$ & $54 \pm 2$ & $64 \pm 2$ & $49 \pm 2$ & $72 \pm 2$ \\
\hline
\end{tabular}

(Table 3). These data shows that in broad terms the cytotoxic potency of bisamidines $\mathbf{1}-\mathbf{3}$ in cultured breast cancer MCF7 cells decreases with the size of the alkyl group substituent (cyclopropyl $>$ isopropyl $>$ cyclopentyl), in accord with their increases in DNA affinity, as shown by the binding constant values (Table 1). This suggests that DNA-binding may be implicated in the cytotoxicity of these bisamidines, possibly by inhibiting interactions between cellular proteins and their DNA targets. The activity of RNA polymerases, DNA polymerases, and topoisomerases I and II can all be affected by bisamidines $\mathbf{1}-\mathbf{3}$ treatment of their DNA templates. We cannot exclude the possibility that the differences in cytotoxicity are due to differences in cell uptake. Further investigations on the mechanisms of the cytotoxicity carried out by these compounds are in progress.

\section{REFERENCES}

1) Denny W. A., Drug Des. Delivery, 3, 99-124 (1988).

2) Boykin D. W., Kumar A., Spychala J., Zhou M., Lombardy R. J., Wilson W. D., Dykstra Ch. C., Jones S. K., Hall J. E., Tidwell R. R., Laughton Ch., Nunn Ch. M., Neidle S., J. Med. Chem., 38, 912-916 (1995).

3) Neidle S., Kelland L. R., Trent J. O., Simpson I. J., Boykin D. W., Kumar A., Wilson W. D., Bioorg. Med. Chem. Lett., 7, 1403-1408 (1997).

4) Chiang S. A. Y., Welch J., Rauscher F. J., Beerman T. A., Biochemistry, 33, 7033 (1994).

5) Broggini M., Ponti M., Ottolenghi S., D’Incalci M., Mongelli N., Mantovani R., Nucleic Acids Res., 17, 1051-1059 (1989).

6) Bailly Ch., Dassonneville L., Carrasco C., Lucas D., Kumar A., Boykin D. W., Wilson W. D., Anti-Cancer Drug Des., 14, 47-60 (1999).

7) Shichita M., Shimazawa R., Nakajima O., Mizoguchi H., Hashimoto Y., Iwasaki S., Biol. Pharm. Bull., 18, 637-639 (1995).

8) Fukutomi R., Kagechika H., Hashimoto Y., Shudo K., Chem. Pharm. Bull., 44, 1983-1985 (1996).

9) Bielawski K., Galicka A., Bielawska A., Sredzinska K., Acta Biochim. Polon., 47, 113-120 (2000).

10) Carmichael J., Degraff W., Gazdar A., Minna J., Mitchell J., Cancer Res., 47, 936-942 (1987).

11) Scatchard G., Ann. N.Y. Acad. Sci., 51, 660-672 (1949).

12) Wilson W. D., Tanious F. A., Barton H. J., Strekowski L., Boykin D. W., J. Am. Chem. Soc., 111, 5008-5010 (1989).

13) Kopka M. L., Yoon C., Goodsell D., Pjura P., Dickerson R. E., Proc. Natl. Acad. Sci. U.S.A., 82, 1376-1380 (1985). 